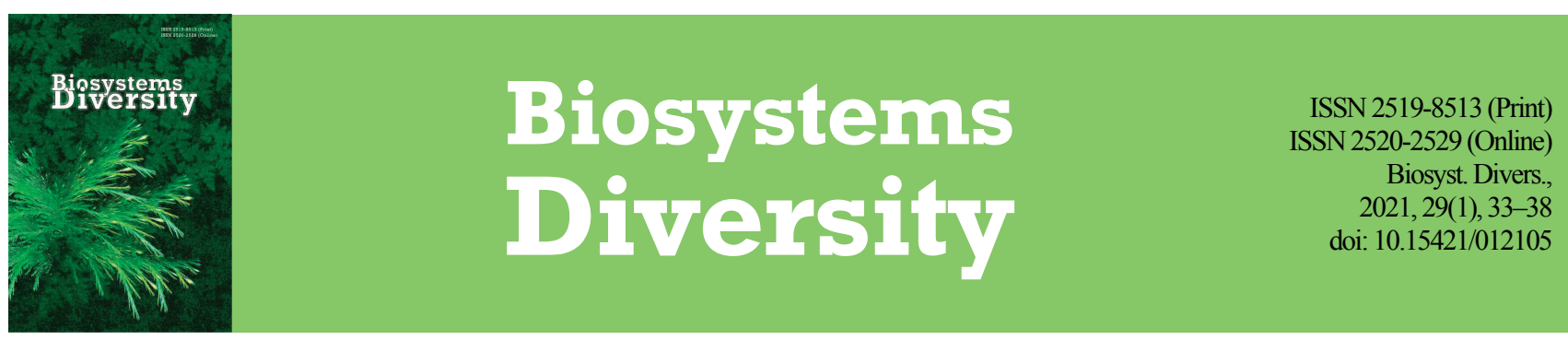

\title{
Regulation of superoxide dismutase activity in soybean plants by inoculating seeds with rhizobia containing nanoparticles of metal carboxylates under conditions of different water supply
}

\author{
V. V. Morgun, S. Y. Kots, T. P. Mamenko, L. I. Rybachenko, P. P. Pukhtaievych \\ Institute of Plant Physiology and Genetics, National Academy of Sciences of Ukraine, Kyiv, Ukraine
}

Article info

Received 28.01.2021

Received in revised form 24.02.2021

Accepted 25.02.2021

Institute of Plant Physiology and Genetics, National Academy of Sciences

of Ukraine, Vasyllkivska st., 31/17, Kyiv, 03022, Ukraine. Tel. $+38-050-964-17-89$

E-mail:tmamenko@ukr.net

\begin{abstract}
Morgun, V. V., Kots, S. Y., Mamenko, T. P., Rybachenko, L. I., \& Pukhtaievych, P. P. (2021). Regulation of superoxide dismutase activity in soybean plants by inoculating seeds with rhizobia containing nanoparticles of metal carboxylates under conditions of different water supply. Biosystems Diversity, 29(1), 33-38. doi:10.15421/012105
\end{abstract}

Soybean is one of the most profitable advanced crops in agricultural production in Ukraine and the world as a whole. Therefore, studies of means of regulation and increase in the adaptive capacity of soybeans in symbiosis with nodule bacteria under the action of unfavourable environmental factors are relevant and should be aimed at the use of complex bacterial compositions involving modern nanotechnological approaches. Nanocarboxylates of ferrum, molybdenum and germanium metals were used as components of rhizobia inoculation suspension for soybean seed treatment to study the effectiveness of their complex effect on the regulation of the activity of the key antioxidant enzyme superoxide dismutase in plants under drought. Various symbiotic systems were used, which included soybean plants and inoculation suspensions based on the active, virulent Tn5-mutant Bradyrhizobium japonicum B1-20 by adding nanoparticles of ferrum, germanium and molybdenum carboxylates to the culture medium in a ratio of 1: 1000. Citric acid was the chelator. A model drought lasting 14 days was created during the period of active fixation of atmospheric molecular nitrogen by root nodules of soybeans in the budding and flowering stages, by means of controlled watering of plants to $30 \%$ of the total moisture content. In the stage of bean formation, watering of plants was resumed to the optimal level $-60 \%$ of the total moisture content. The control was soybean plants, the seeds of which were inoculated with a suspension of rhizobia without the addition of chelated metals. The following research methods were used in the work - microbiological, physiological and biochemical. According to the results, it was found that when nanoparticles of carboxylates of ferrum, molybdenum and germanium were added to the inoculation suspension of rhizobia, there was an increase in superoxide dismutase activity in root nodules and a decrease in soybean leaves under optimal water supply conditions of plants. This indicates the initial changes in the activity of the antioxidant enzyme in these symbiotic systems, induced by the influence of chelated metals in combination with the rhizobia of the active Tn5-mutant B. japonicum B1-20. Prolonged drought induced an increase in the overall level of superoxide dismutase activity in soybean nodules and leaves, compared to plants grown under optimal watering conditions. The symbiotic system formed by soybeans and $B$. japonicum with molybdenum carboxylate nanoparticles was the most sensitive to long-term drought exposure, compared to two other soybean-rhizobial symbioses using ferrum and germanium nanocarboxylates. This was manifested in the unstable reaction of the enzyme to the action of drought - suppression or intensification of the level of its activity in the root nodules and leaves of soybeans inoculated with rhizobia containing molybdenum carboxylate nanoparticles. In symbiotic systems with the participation of germanium and ferrum nanocarboxylates, slight changes were revealed in superoxide dismutase activity in root nodules and leaves of plants during drought and restoration of enzyme activity to the level of plants with optimal watering after water stress. It is concluded that the addition to the culture medium of rhizobia Tn5-mutant B1-20 of nanocarboxylates of germanium or ferrum is an effective means of regulating the activity of the antioxidant enzyme superoxide dismutase in soybean root nodules and leaves, which can contribute to an increase in the protective properties and adaptation of plants to the action of dehydration.

Keywords: Glycine max; Bradyrhizobium japonicum; antioxidant enzymes; symbiotic system; germanium; ferrum; molybdenum.

Introduction

In the plant organism, there is a physiologically normal level of free radical processes, which is necessary to regulate the phase state of lipids, membrane permeability, and a number of biosynthetic processes (Mhamdi \& Van Breusegem, 2018). This steady state is determined by the functioning of a complex system of free radical oxidation inhibitors (Foyer \& Noctor, 2005). Changes in the properties of membrane structures and cell metabolism that occur as a result of activation of lipid peroxidation under the action of stressors are among the initial, primary links in the chain of processes that lead to the formation of a state of stress. At the same time, the activation of antioxidant systems is a factor that gives the plant organism increased stability (Laxa et al., 2019).

The main initiator of free radical oxidation of membrane lipids is considered to be superoxide, which is generated in many spontaneous and enzymatic oxidation reactions, and the products of its secondary transformation can be singlet oxygen, hydroxyl radical, hydrogen peroxide, orga- nic peroxides and their radicals. The antioxidant enzyme superoxide dismutase is considered to be crucial in protecting plant cells from oxidative degradation due to the development of oxidative stress caused by external factors (Alscher et al., 2020). It is involved in the utilization of superoxide radical anions to hydrogen peroxide and water. However, the effective operation of superoxide dismutase requires a complex of enzymes that will utilize the hydrogen peroxide formed as a result of the dismutation reaction. These enzymes include enzymes such as catalase, peroxidase, glutathione transferase, etc. (Sarker \& Oba, 2018; Hasanuzzaman et al., 2019; Tyagi et al., 2020). Different isoforms of enzymes-antioxidants work in different compartments - chloroplasts, cytosols, peroxisomes, where reactive oxygen species are formed in the process of various redox reactions (Rubio et al., 2005; Asensio et al., 2011; Tyagi et al., 2017).

Superoxide dismutases belong to the group of metalloenzymes and, depending on the metal in the cofactor, emit Fe- (iron), Mn- (manganese) CuZn- (copper-zinc) dependent superoxide dismutase (SOD) (respectively FeSOD, MnSOD and CuZnSOD) (Moran et al., 2003; Talukdar \& 
Talukdar, 2013). All of these isoenzymes are present in the root nodules of legumes, although they have different subcellular localization, which determines their specific functions (Becana et al., 2010; de Deus et al., 2015). In nondeterministic nodules of Medicago sativa and Pisum sativum, transcripts of cytosolic CuZnSODs are found predominantly in the meristem, infection zone, and nitrogen fixation zone (Rubio et al., 2004). In this case, $\mathrm{CuZnSOD}$ is localized in the cytoplasm, namely in the areas adjacent to the cell walls, the walls of the infection threads, and also in the matrix of the infection threads. In addition, this isoenzyme is found in the intercellular spaces of cortex cells and in cells in the nitrogen fixation zone (Rubio et al., 2004; Asensio et al., 2012). MnSOD is localized mainly in the zone of nitrogen fixation, and is also present inside infectious filaments of bacteria, in bacteroids and mitochondria. In the nodules, a common localization of hydrogen peroxide was detected with $\mathrm{CuZnCOD}$, and not with MnCOD. Thus, $\mathrm{CuZnCOD}$ is one of the most important sources of hydrogen peroxide in root nodules, which is important for the formation and growth of infectious filaments (Wisniewski et al., 2000). Bacteroids contain MnSOD in the cytosol and CuZnSOD in the periplasmic space. These enzymes are encoded by the corresponding bacterial sodA and sodC genes (Santos et al., 2000). Transcriptomic analysis of Medicago truncatula nodules showed that genes encoding $\mathrm{CuZnSOD}$ and mitochondrial MnSOD isoforms are actively expressed in root nodules, while cytosolic FeSOD gene expression remains relatively low (Benedito et al., 2008).

It has been proven that in determinate nodules of Lotus japonicus, the expression of the genes of cytosolic CuZnSOD and mitochondrial MnSOD, the number and activity of enzymes decreases with age. In young nodules, $\mathrm{CuZnSOD}$ is localized in cells that are dividing, as well as in infectious filaments and infected cells. At the same time, the transcription of FeSOD II, which encodes cytosolic FeSOD, is activated with age, while FeSOD I, which encodes plastid FeSOD, does not change. It is believed that two cytosolic enzymes, $\mathrm{CuZnSOD}$ and FeSOD II, are capable of functionally compensating each other at the late stages of nodule development. In addition, the induction of FeSOD II is associated with an increase in Fe availability in senescent nodules as a result of leghemoglobin degradation (Rubio et al., 2007).

It is proved that the activity of superoxide dismutase can change in different ways: in some cases there is an increase, in others - a decrease depending on the intensity of the stress factor (intensity and duration of action), as well as the adaptability of the plant organism (Matamoros et al., 2003; Laxa, 2019). Under salt stress, the activity of FeSOD in the root nodules of Phaseolus vulgaris increases, while the activity of CuZnSOD and MnSOD does not change (Tejera et al., 2004; Jebara et al., 2005). In Arachis hypogaea plants, under drought conditions, the number of $\mathrm{CuZnSOD}$ transcripts in the root nodules increases, while the activity of MnSOD does not change (Furlan et al., 2014). The opposite results were obtained with respect to superoxide dismutase activity in Pisum sativum and Glycine max tubers under drought. In the first case, a decrease in the activity of superoxide dismutase was revealed, in the second, its increase (Gogorcena et al., 1995; Porcel et al., 2003). This difference in the reaction of superoxide dismutase isoenzymes in different legume species emphasizes the need to study gene expression and regulation of enzyme activity in more detail (Ivanova \& Cygankov, 2017).

The discovery of the peculiarities of the formation of protective reactions of soybean plants under the action of stressors of various natures, including drought, is important to determine the participation of antioxidant enzymes in the adaptation potential of plants in symbiosis with nodule bacteria. The search for effective means to regulate and mobilize the protective reactions of plants under stress is necessary to increase their adaptation to adverse growing conditions. In this aspect, special attention should be paid to the development of bacterial compositions containing both nitrogen-fixing microorganisms and chelated metal compounds in the form of carboxylate nanoparticles. This will become an important direction in solving the problem of micronutrient nutrition in legumes. It is shown that the addition of germanium and iron compounds chelated with carboxylic acids to the inoculation suspension leads to increased nitrogenfixing activity of symbiotic systems of soybean- $B$. japonicum, and when molybdenum is added, soybean yield is increased under optimal plant growing conditions (Kots et al., 2019).
Previously, we studied changes in the activity of antioxidant enzymes in soybean plants in symbiosis with strains and Tn5 mutants of B. japonicum, which differ in symbiotic properties - virulence and fixation activity of molecular nitrogen in the atmosphere. It was shown that the symbiotic system with the participation of nodule bacteria Tn5-mutant B1-20 differed among other soybean symbioses in maintaining the functioning of the nitrogen-fixing apparatus under drought conditions. This was due to the regulation of prooxidant-antioxidant processes towards the activation of protective antioxidant enzymes, including superoxide dismutase (Mamenko et al., 2018).

Nanocarboxylates of ferrum, molybdenum and germanium metals were used as components of rhizobia inoculation suspension for soybean seed treatment to study the effectiveness of their complex effect on the regulation of the activity of the key antioxidant enzyme superoxide dismutase in plants under drought.

\section{Materials and method}

The objects of study were symbiotic systems formed with the participation of soybean plants (Glycine $\max (\mathrm{L}$.) Merr.) varieties Almaz and Bradyrhizobium japonicum Tn5-mutant B1-20 for the addition of carboxylates of metals ferrum (Fe), germanium $(\mathrm{Ge})$ and molybdenum (Mo). The work used an active, virulent Tn5-mutant $B$. japonicum B1-20 from the museum collection of nitrogen-fixing microorganisms of the symbiotic nitrogen fixation department, which was deposited at the D. K. Zabolotny Institute of Microbiology and Virology with registration number B7538 (Kots \& Vorobei, 2018). Before sowing, soybean seeds were inoculated with a culture of rhizobia containing nanocarboxylates of microelements ferrum, germanium and molybdenum. Some of the soybean seeds were inoculated with a pure culture of rhizobia without adding chelated metals to the culture medium.

The culture of slow-growing nodule bacteria was grown at $26-28^{\circ} \mathrm{C}$ for 9 days on mannitol-yeast medium, in which chelated metals (nanocarboxylates of microelements) of ferrum $(\mathrm{Fe})$, germanium $(\mathrm{Ge})$, molybdenum (Mo) were added in a ratio of 1:1000. Citric acid was the chelator. The microelement preparations used by us are provided by LLC Scientific and Production Company "Avatar" (Kyiv, Ukraine). They are obtained in two stages: 1 - obtaining an aqueous colloidal solution of nanoparticles of microelements by dispersing highly purified granules of the corresponding metals by pulses of electric current in deionized water (Kosinov \& Kaplunenko, 2008); 2 - obtaining metal carboxylates by the reaction of direct interaction of the obtained nanoparticles with food carboxylic acid (Kaplunenko \& Kosinov, 2009).

The bacteria were cultivated in Erlenmeyer flasks containing $200 \mathrm{~mL}$ of nutrient medium by the method of periodic incubation on a circular shaker with a rotation speed of $220 \mathrm{rpm}$. $/ \mathrm{min}$. The inoculum was introduced into the flasks at a concentration of $2 \%$ of the volume of the nutrient medium. The number of rhizobia in the suspension introduced into the nutrient medium was 108 cells $/ \mathrm{mL}$.

The plants were grown in sand culture on a nutrient medium of Helrigel with 0.25 nitrogen under natural light and optimal water supply $60 \%$ of total moisture content. The duration of the drought for 14 days was created during the period of active fixation of molecular nitrogen in the atmosphere by the nodules of soybean roots - the budding and flowering stages, using controlled watering of plants up to $30 \%$ of total moisture content. In the stage of bean formation, watering of plants was resumed to the optimal level $-60 \%$ of total moisture content within 7 days. The control was soybean plants, the seeds of which were inoculated with a suspension of rhizobia without the addition of chelated metals.

To obtain the enzyme extract, the weight of the plant material was homogenized with a cooled $60 \mathrm{mM}$ phosphate buffer ( $\mathrm{pH} 7.5)$ containing $2 \mathrm{mM}$ ethylenediaminetetraacetic acid, $1 \mathrm{mM}$ phenylmethylsulfonyl fluoride, $5 \mathrm{mM} \beta$-mercaptoethanol and $1 \%$ polyvinylpyrrolidone. The homogenate was centrifuged at $10,000 \mathrm{rpm}$ for 20 minutes at $4{ }^{\circ} \mathrm{C}$. The supernatant was used to determine the activity of enzymes using the UV-1900 scanning two-beam spectrophotometer (Shimadzu, Japan). Superoxide dismutase activity (EC 1.15.1.1) was determined by the ability of the enzyme to inhibit the photochemical reduction of nitro blue tetrazolium chloride (NBT) (Alscher et al., 2002). The reaction mixture contained $60 \mathrm{mM}$ 
phosphate buffer (pH 7.8), $13 \mathrm{mM}$ methionine, $2 \mu \mathrm{m}$ riboflavin, $63 \mu \mathrm{m}$ p-nitro blue tetrazolium chloride, $0.1 \mathrm{mM}$ ethylenediaminetetraacetic acid, and $100 \mu \mathrm{L}$ of enzyme extract. The assay consists of a purely chemical sequence of reactions including $13 \mathrm{mM}$ methionine, $2 \mu \mathrm{m}$ riboflavin, $63 \mu \mathrm{m}$ p-nitro blue tetrazolium chloride, $0.1 \mathrm{mM}$ ethylenediaminetetraacetic acid, and $100 \mu \mathrm{L}$ of enzyme extract. The reaction was initiated by illumination with fluorescent lamps with a power of $15 \mathrm{~W}$ and a light intensity of $70 \mu \mathrm{mol}$ quanta $/\left(\mathrm{m}^{2} \cdot \mathrm{s}\right)$ for $15 \mathrm{~min}$. The optical density was measured at $560 \mathrm{~nm}$. The results are presented in units of activity of the enzyme on the concentration of protein ( $\mathrm{mg}$ ) in the supernatant. The content of total soluble protein in the enzyme extract was determined by Bradford (1976). Analysis of the data was made using Statistica 6.0 (StatSoft Inc., USA) program. The data are presented in tables as $\mathrm{x} \pm \mathrm{SD}(\mathrm{x} \pm$ standard deviation). Differences between the values in the control and experimental groups were determined using the Tukey test, where the differences were considered reliable at $\mathrm{P}<0.05$ (taking into account the Bonferroni correction).

\section{Results}

Under optimal plant growing conditions, the activity of superoxide dismutase in soybean root nodules inoculated by rhizobia with the addition of metal carboxylate nanoparticles was higher compared to the level of its activity in plants of the symbiotic system without the use of chelated metals (Table 1). Treatment of soybean seeds with an inoculation suspension containing germanium carboxylate showed an increase in enzyme activity in root nodules during the following stages of ontogenesis by $16.6 \%$ at thestage of three true leaves, $34.2 \%$ at the stage of budding, $53.9 \%$ at the stage of of flowering and $77.6 \%$ at the stage of of bean formation. The use of the inoculation suspension with molybdenum carboxylate nanoparticles did not cause significant changes in the activity of the enzyme in the stage of the three true leaves. However, it led to an increase in superoxide dismutase activity in soybean root nodules from the budding stage to the formation of beans by $28.3-30.5 \%$. The complex inoculation of soybeans seeds with ferrum nanocarboxylate, the activity of the enzyme in root nodules increased by $27.4 \%$ in the stage of three true leaves, increased insignificantly during the budding and flowering stages, and increased by $45.4 \%$ in the stage of bean formation, compared with plants in symbiosis with rhizobia without the use of chelated metals.

\section{Table 1}

The effect of inoculation of soybean seeds Bradyrhizobium japonicum with the content of metal carboxylate nanoparticles on the activity of superoxide dismutase in root nodules, under optimal water supply ( $60 \%$ of total moisture content, units act./mg protein, $\mathrm{x} \pm \mathrm{SD}, \mathrm{n}=6$ )

\begin{tabular}{lcccc}
\hline \multirow{2}{*}{ Variants } & \multicolumn{4}{c}{ Stages of ontogenesis } \\
\cline { 2 - 5 } & three true leaves & budding & flowering & $\begin{array}{c}\text { bean forma- } \\
\text { tion }\end{array}$ \\
\hline $\begin{array}{l}\text { B.japonicum } \mathrm{B} 1-20 \\
\text { B.japonicum } \mathrm{B} 1-20\end{array}$ & $46.6 \pm 3.3^{\mathrm{a}}$ & $42.2 \pm 3.1^{\mathrm{a}}$ & $51.8 \pm 3.6^{\mathrm{a}}$ & $45.7 \pm 3.2^{\mathrm{a}}$ \\
+ ferrum & $59.4 \pm 4.2^{\mathrm{b}}$ & $50.1 \pm 3.6^{\mathrm{b}}$ & $57.1 \pm 4.1^{\mathrm{a}}$ & $66.5 \pm 4.6^{\mathrm{b}}$ \\
$\begin{array}{l}\text { B.japonicum } \mathrm{B} 1-20 \\
+ \text { germanium }\end{array}$ & $54.3 \pm 3.8^{\mathrm{b}}$ & $56.6 \pm 4.1^{\mathrm{b}}$ & $79.8 \pm 5.5^{\mathrm{b}}$ & $81.2 \pm 5.6^{\mathrm{c}}$ \\
$\begin{array}{l}\text { B.japonicum } \mathrm{B} 1-20 \\
+ \text { molybdenum }\end{array}$ & $50.2 \pm 2.7^{\mathrm{ab}}$ & $54.1 \pm 3.5^{\mathrm{b}}$ & $65.9 \pm 4.6^{\mathrm{c}}$ & $59.6 \pm 4.1^{\mathrm{d}}$ \\
\hline
\end{tabular}

Note: different letters indicate values that differ significantly from each other in the same columns of the table by comparison with the Tukey test, $\mathrm{P}<0.05$ (taking into account the Bonferroni correction).

Prolonged drought in the budding and flowering stages led to an increase in the overall level of superoxide dismutase activity in soybean root nodules in all variants of the experiment (Table 1,2). The highest enzyme activity was observed in soybean root nodules by inoculation of seeds with rhizobia without the use of metal carboxylates. Thus, under the action of drought in the budding stage, its activity increased by $151.9 \%$ and did not increase significantly during the flowering stage $-21.3 \%$. After resumption of watering of plants in the stage of bean formation, its activity intensified by $218.2 \%$, in comparison with non-inoculated plants, which were grown under optimal watering conditions.

In soybean inoculated with rhizobia containing ferrum carboxylate nanoparticles, there were no significant changes in the activity of super- oxide dismutase in root nodules due to the action of drought in the budding stage and a decrease in its activity by $25.1 \%$ in the flowering stage, compared with plants of the symbiotic system without the use of chelated metals, which also grew in arid conditions (Table 2). When using soybean seed inoculation suspensions containing germanium carboxylate nanoparticles, no significant differences were observed in the response of the antioxidant enzyme in root nodules to drought, compared to plants in symbiosis with $B$. japonicum, without the use of chelated metals, which also grew in arid conditions. When rhizobia suspension containing molybdenum nanoparticles was used for inoculation of soybean seeds, the activity of superoxide dismutase in root nodules was reduced by $20.6 \%$ due to drought in the budding stage and increased by $29.5 \%$ in the flowering stage, compared with plants of the symbiotic system without use chelated metals, which also grew in arid conditions.

After resumption of plant watering, in the stage of bean formation, almost the same level of increase in the activity of superoxide dismutase in the nodules of soybean roots inoculated with rhizobia containing nanocarboxylates of ferrum, molybdenum and germanium was shown (Table 2). However, the activity of the enzyme in symbiotic systems with the participation of chelated microelements was lower, compared with plants of the symbiotic system without the use of chelated metals. This difference is due to the rapid increase in its level of activity in the root nodules of soybeans inoculated with rhizobia without adding to the culture medium chelated microelements, after the action of water stress.

\section{Table 2}

The effect of inoculation of soybean seeds Bradyrhizobium japonicum with the content of metal carboxylate nanoparticles on the activity of superoxide dismutase in root nodules, under the influence of insufficient water supply (units act./mg protein, $\mathrm{x} \pm \mathrm{SD}, \mathrm{n}=6$ )

\begin{tabular}{|c|c|c|c|}
\hline \multirow[b]{3}{*}{ Variants } & \multicolumn{3}{|c|}{ Stages of ontogenesis } \\
\hline & budding & flowering & bean formation \\
\hline & $\begin{array}{r}\text { drought } f \\
\text { (30\% of total n }\end{array}$ & $\begin{array}{l}4 \text { days } \\
\text { ture content) }\end{array}$ & $\begin{array}{l}\text { watering restoration for } 7 \text { days } \\
\text { (60\% of total moisture con- } \\
\text { tent) }\end{array}$ \\
\hline B. japonicum $\mathrm{B} 1-20$ & $106.3 \pm 7.1^{\mathrm{a}}$ & $62.8 \pm 4.4^{\mathrm{a}}$ & $145.5 \pm 10.8^{\mathrm{a}}$ \\
\hline $\begin{array}{l}\text { B. japonicum B1-20 } \\
+ \text { ferum }\end{array}$ & $112.1 \pm 7.5^{\mathrm{a}}$ & $47.1 \pm 5.3^{\mathrm{b}}$ & $97.6 \pm 6.8^{b}$ \\
\hline $\begin{array}{l}\text { B. japonicum B1-20 } \\
+ \text { germanium }\end{array}$ & $91.4 \pm 6.4^{b}$ & $63.5 \pm 4.6^{\mathrm{a}}$ & $96.8 \pm 6.7^{b}$ \\
\hline $\begin{array}{l}\text { B. japonicum B1-20 } \\
+ \text { molybdenum }\end{array}$ & $84.3 \pm 5.8^{c}$ & $81.4 \pm 5.7^{\mathrm{c}}$ & $99.4 \pm 7.1^{b}$ \\
\hline
\end{tabular}

Note: see Table 1.

Under optimal water supply conditions, soybeans inoculated with rhizobia containing chelated metals showed a decrease in superoxide dismutase activity in the leaves, compared with plants in symbiosis with B. japonicum without the use of chelated metals (Table 3). The most significant decrease in enzyme activity in soybean leaves was observed in the variant with the use of ferrum carboxylate nanoparticles in the stage of three true leaves by $47.1 \%$, in the budding stage by $36.2 \%$, in the flowering stage by $41.4 \%$ and a slight decrease in its activity by $15.7 \%$ in the stage of beans formation. With the use of germanium carboxylate nanoparticles, the enzyme activity in the leaves decreased in the stages of three true leaves and budding by $36.5 \%$ and $21.7 \%$, respectively, and did not change significantly in subsequent stageses of ontogenesis, compared with plants of the symbiotic system without the use of chelated microelements. When using molybdenum nanoparticles, no significant changes in the activity of the enzyme in the leaves were determined, compared with inoculated plants without the use of chelated metals, at the initial stages of ontogenesis until the stage of bean formation, when the level of its activity decreased by $26.6 \%$. Under moderate exposure to water stress in the budding stage, the activity of superoxide dismutase in soybean leaves inoculated with rhizobia without the use of chelated metals decreased by $22.5 \%$, compared with plants with optimal watering (Table 3, 4). During prolonged dehydration in the flowering stage, the enzyme activity in the leaves increased by $22.2 \%$, and after the action of water stress in the bean formation stage was restored to the level of plants with optimal water supply.

When soybean seed inoculation with rhizobia together with ferrum carboxylate nanoparticles was used, no significant changes in superoxide dismutase activity in soybean leaves were observed during drought in the 
budding stage and a slight decrease was observed in its activity in the flowering stage by $12.5 \%$ compared to plants in symbiosis with $B$. japonicum without the use of chelated metals symbiotic (Table 4). Treatment of soybean seeds with rhizobia together with germanium carboxylate nanoparticles showed similar dynamics of enzyme activity in the leaves during drought, as in the case of ferrum nanocarboxylate. In particular, the absence of significant changes in the activity of superoxide dismutase in the leaves under the action of drought in the budding stage and a slight decrease in its activity level by $16.1 \%$ under the action of drought in the flowering stage. The use of soybean inoculation simultaneously with molybdenum carboxylate nanoparticles did not change the activity of superoxide dismutase in the leaves under the action of drought in the budding stage and increase its activity by $38.5 \%$ under the action of dehydration in the flowering stage.

\section{Table 3}

The effect of inoculation of soybean seeds Bradyrhizobium japonicum with the content of metal carboxylate nanoparticles on the activity of superoxide dismutase in leaves, under optimal water supply ( $60 \%$ of total moisture content, units act. $/ \mathrm{mg}$ protein, $\mathrm{x} \pm \mathrm{SD}, \mathrm{n}=6$ )

\begin{tabular}{lcccc}
\hline \multirow{2}{*}{ Variants } & \multicolumn{4}{c}{ Stages of ontogenesis } \\
\cline { 2 - 5 } & $\begin{array}{c}\text { three true } \\
\text { leaves }\end{array}$ & budding & flowering & $\begin{array}{c}\text { bean } \\
\text { formation }\end{array}$ \\
\hline $\begin{array}{l}\text { B.japonicum } \text { B1-20 } \\
\text { B.japonicum } \text { B1-20 }\end{array}$ & $125.2 \pm 8.7^{\mathrm{a}}$ & $121.3 \pm 8.5^{\mathrm{a}}$ & $118.8 \pm 8.3^{\mathrm{a}}$ & $117.8 \pm 8.2^{\mathrm{a}}$ \\
+ ferrum & $66.1 \pm 4.6^{\mathrm{b}}$ & $77.3 \pm 5.4^{\mathrm{b}}$ & $69.6 \pm 4.8^{\mathrm{b}}$ & $99.3 \pm 6.9^{\mathrm{b}}$ \\
$\begin{array}{l}\text { B.japonicum } \mathrm{B} 1-20 \\
\text { + germanium }\end{array}$ & $79.4 \pm 5.5^{\mathrm{c}}$ & $95.0 \pm 6.6^{\mathrm{c}}$ & $95.5 \pm 6.7^{\mathrm{c}}$ & $93.1 \pm 6.5^{\mathrm{bc}}$ \\
$\begin{array}{l}\text { B.japonicum } \mathrm{B} 1-20 \\
\text { + molybdenum }\end{array}$ & $117.2 \pm 8.2^{\mathrm{a}}$ & $106.6 \pm 7.6^{\mathrm{ac}}$ & $107.4 \pm 7.5^{\mathrm{ac}}$ & $86.4 \pm 6.1^{\mathrm{c}}$ \\
\hline
\end{tabular}

Note: see Table 1.

\section{Table 4}

The effect of inoculation of soybean seeds Bradyrhizobium japonicum with the content of metal carboxylate nanoparticles on the activity of superoxide dismutase in leaves, under the influence of insufficient water supply (units act./mg protein, $\mathrm{x} \pm \mathrm{SD}, \mathrm{n}=6$ )

\begin{tabular}{|c|c|c|c|}
\hline \multirow[b]{3}{*}{ Variants } & \multicolumn{3}{|c|}{ Stages of ontogenesis } \\
\hline & budding & flowering & bean formation \\
\hline & $\begin{array}{l}\text { drought for } \\
\text { of total moi }\end{array}$ & $\begin{array}{l}4 \text { days ( } 30 \% \\
\text { ture content) }\end{array}$ & $\begin{array}{l}\text { watering restoration for } 7 \\
\text { days ( } 60 \% \text { of total moisture } \\
\text { content) }\end{array}$ \\
\hline B. japonicum $\mathrm{B} 1-20$ & $93.8 \pm 6.6^{\mathrm{a}}$ & $145.3 \pm 10.2^{\mathrm{a}}$ & $121.2 \pm 8.5^{\mathrm{a}}$ \\
\hline $\begin{array}{l}\text { B. japonicum } \mathrm{B} 1-20+ \\
\text { ferrum }\end{array}$ & $102.2 \pm 7.2^{b}$ & $127.1 \pm 8.8^{\mathrm{b}}$ & $139.9 \pm 9.8^{b}$ \\
\hline $\begin{array}{l}\text { B. japonicum } \mathrm{B} 1-20+ \\
\text { germanium }\end{array}$ & $103.4 \pm 7.9^{b}$ & $121.8 \pm 8.5^{\mathrm{b}}$ & $117.8 \pm 8.2^{\mathrm{a}}$ \\
\hline $\begin{array}{l}\text { B. japonicum } \mathrm{B} 1-20+ \\
\text { molybdenum }\end{array}$ & $87.2 \pm 6.1^{\mathrm{a}}$ & $201.2 \pm 14.2^{\mathrm{c}}$ & $126.5 \pm 8.8^{\mathrm{ab}}$ \\
\hline
\end{tabular}

Note: see Table 1.

In the post-stress period, it was recorded that in the variants of the experiment with inoculation of soybean seeds with rhizobia in combination with chelated metals germanium and molybdenum, the activity of the enzyme in the leaves was approximately the same and did not differ from the level of its activity in symbiotic plants without metal nanocarboxylates (Table 4). However, in the symbiotic system with the participation of ferrum nanocarboxylate, the activity of superoxide dismutase in the leaves increased slightly by $15.5 \%$ after the resumption of watering plants in the stage of bean formation.

\section{Discussion}

The activity of superoxide dismutase is regulated depending on the metabolic needs of the cell, which are determined by the intensity of stress exposure, its duration, the degree of plant sensitivity, etc. (Udvardi \& Poole, 2013; Laxa, 2019). It is believed that reactive oxygen species, calcium ions, nitric oxide, glutathione, as well as phytohormones, in particular abscisic and salicylic acids, are involved in the signal transduction pathways that lead to the activation of superoxide dismutase and the expression of its genes (Pauly et al., 2006; Suzuki et al., 2012; Palma et al., 2013; Udvardi
$\&$ Poole, 2013). The increase in superoxide dismutase activity is a response to the increase in the production of superoxide radicals due to the activation of its latent forms or the synthesis of new macromolecules. However, at a certain level of oxidative stress there is a decrease in superoxide dismutase activity, which is associated with depletion of the enzyme pool due to increased utilization of superoxide radicals, reduced synthesis or increased dehydration of its molecules (Alscher et al., 2002; Tyagi et al., 2017).

The analysis of the obtained results showed that when soybean seeds are inoculated with a culture of rhizobia Tn5-mutant B1-20 containing nanoparticles of metal carboxylates, changes in superoxide dismutase activity in root nodules and leaves of soybeans occur under optimal conditions of plant growth during ontogenesis from the stage of three true leaves to the formation of beans. This is manifested in an increase in the activity of the enzyme in the root nodules and a decrease in its activity in soybean leaves by adding metal nanocarboxylates to the inoculation suspension, compared with plants in symbiosis with rhizobia without the use of chelated microelements. Such dynamics of enzyme activity were most indicative for root nodules in the variant of inoculation of soybean seeds with rhizobia suspension containing germanium nanoparticles and for leaves - when ferrum nanoparticles were added to the culture medium of $B$. japonicum. This indicates the initial changes in the activity of the antioxidant enzyme in these symbiotic systems, induced by the action of chelated microelements in combination with the inoculation of soybean seeds with rhizobia of the Tn5-mutant B1-20.

Prolonged drought leads to an increase in the overall level of superoxide dismutase activity in root nodules and soybean leaves, compared to plants grown under optimal watering conditions.

In soybeans in symbiosis with nodule bacteria Tn5-mutant B1-20 for the addition of ferrum nanocarboxylate, no significant changes in the activity of superoxide dismutase in root nodules and leaves were recorded due to the action of dehydration in the budding stage and a decrease in the level of its activity in these plant organs due to the action of drought in the flowering stage. Inoculation of soybean B. japonicum with molybdenum carboxylate nanoparticles under dehydration was observed to inhibit superoxide dismutase activity in root nodules during the budding stage. However, there was an increase in its activity in root nodules and leaves under prolonged exposure to water stress during the flowering stage. Soybeans inoculated with rhizobia containing germanium carboxylate nanoparticles did not show significant changes in superoxide dismutase activity in root nodules due to drought and a slight decrease in the level of its activity in leaves due to dehydration during the flowering stage.

After the action of water stress in all symbiotic systems formed with the participation of soybean plants, B. japonicum Tn5-mutant B1-20 and chelated microelements, approximately the same level of enzyme activity was found in root nodules and leaves, which was almost at the level of plants with optimal watering. The only exception was increase in enzyme activity in leaves of soybean in symbiosis with rhizobia with the addition of ferrum carboxylate nanoparticles.

It is believed that trace elements of metals in very low concentrations can be used as a kind of stress factor of very low levels (Taran et al., 2016). Their action in accordance with the principle of hormesis, can indirectly contribute to the development of adaptive potential of plants by inducing changes in the course of certain biochemical reactions in plant cells (Taran et al., 2016). It is shown that the use of micronutrient nanoparticles significantly changes physiological and biochemical processes in plants, in particular, it increases the activity of enzymes, intensifies photosynthetic processes, and improves mineral nutrition of plants (Kole et al., 2013; Du et al., 2015). The role of chemical properties of metal nanoparticles for modulation of the antioxidant defense system and physiological processes involved in the development of adaptive reactions of plants is shown (Taran et al., 2016). It has been shown that various metal nanoparticles exhibit antioxidant ability and exhibit enzyme-like properties. In particular, nanoparticles of cerium $\left(\mathrm{nCeO}_{2}\right)$ and iron $\left(\mathrm{nFe}_{3} \mathrm{O}_{4}\right)$ oxides exhibit catalase-like activity; and oxides of cerium $\left(\mathrm{nCeO}_{2}\right)$, iron $\left(\mathrm{nFe}_{3} \mathrm{O}_{4}\right)$, cobalt $\left(\mathrm{nCo}_{3} \mathrm{O}_{4}\right)$, manganese $\left(\mathrm{nMnO}_{2}\right)$, copper $(\mathrm{nCuO})$ and nanoparticles of aurum $(\mathrm{nAu})-$ to peroxidase; cerium oxide $\left(\mathrm{nCeO}_{2}\right)$, platinum $(\mathrm{nPt})$ and fullerene nanoparticles exhibit properties similar to superoxide dismutase (Wu et al., 2015). It has been found that treatment of isolated Vigna radiata chloroplasts with manganese nanoparticles (nMn) modulates the activity of photosys- 
tem II by increasing water cleavage and oxygen evolution, which increases the activity of photophosphorylation processes in the electron transport chain (Pradhan et al., 2013). The use of germanium, iron and molybdenum nanocarboxylates as components of the inoculation suspension induces an increase in nitrogen-fixing activity and optimization of photosynthetic processes in soybean plants in symbiosis with nodule bacteria (Kots et al., 2019).

To date, there are no unequivocal beliefs about the influence of metal nanoparticles on the course of physiological and biochemical processes in plants, which proves the relevance of further research in this direction. This will clarify the role of chelated microelements in maintaining the homeostasis of plant cells under the action of external factors of various natures.

Despite a significant number of studies on the participation of antioxidant enzymes, including superoxide dimutase, in the formation of protective reactions of legumes in symbiosis with nodule bacteria under drought, the mechanism of this phenomenon is still not fully understood (Becana et al., 2010; Asensio et al., 2011; Kunert et al., 2016; Gutiérrez-Martínez et al., 2020). Superoxide dismutase does not provide complete protection of the cell from oxidative stress, because its work produces hydrogen peroxide, which is an inhibitor of the enzyme. Therefore, the effective functioning of this enzyme is largely determined by the functioning of other components of the defense system, in particular, those that utilize hydrogen peroxide (catalase, peroxidase) and enzymes of the ascorbate-glutathione cycle (Sarker \& Oba, 2018; Hasanuzzaman et al., 2019; Tyagi et al., 2020). We have previously shown that the formation of defense reactions in soybeans in symbiosis with $B$. japonicum under the influence of drought is associated with the activation of superoxide dismutase, adaptive changes in the activity of catalase and ascorbate peroxidase in root nodules, roots and leaves, which induce the regulation of peroxide content and the intensity of lipid peroxidation processes (Mamenko et al., 2019). In our opinion, further research should focus on studying the effect of chelated micronutrients on the antioxidant status of plant cells. This will show their participation in the formation of protective reactions of legumes and the possibility of joint use with nodule bacteria to increase the adaptability and productive potential of legume-rhizobial symbiosis under drought.

\section{Conclusions}

The use of nanoparticles of molybdenum, ferrum and germanium in combination with rhizobia Tn5-mutant B1-20 leads to changes in the activity of the antioxidant enzyme superoxide dismutase in soybean plants an increase in root nodules and a decrease in leaves under optimal growing conditions. In drought conditions, unstable dynamics of antioxidant enzyme activity were detected - inhibition or intensification in soybean root nodules and leaves inoculated with rhizobia containing molybdenum carboxylate nanoparticles, which indicates the sensitivity of this symbiotic system to water stress.

The addition of nanoparticles of germanium or ferrum carboxylates to the inoculation suspension of rhizobia of the Tn5 mutant B1-20 showed insignificant changes in the enzyme activity in root nodules and soybean leaves during dehydration and after exposure to water stress, which indicates a high tolerance of these symbioses to growing conditions.

\section{References}

Alscher, R. G., Erturk, N., \& Heath, L. S. (2002). Role of superoxide dismutases (SODs) in controlling oxidative stress in plants. Joumal of Experimental Botany, 53(372), 1331-1341.

Asensio, A. C., Gil-Monreal, M., Pires, L., Gogorcen, Y., Aparicio-Tejo, P. M., \& Moran, J. F. (2012). Two Fe-superoxide dismutase families respond differently to stress and senescence in legumes. Journal of Plant Physiology, 169(13), $1253-1260$.

Asensio, A. C., Marino, D., James, E. K., Ariz, I., Arrese-Igor, C., Aparicio-Tejo, P. M., Arredondo-Peter, R., \& Moran, J. F. (2011). Expression and localization of a Rhizobium-derived cambialistic superoxide dismutase in pea (Pisum sativum) nodules subjected to oxidative stress. Molecular Plant-Microbe Interactions, 24(10), 1247-1257.

Becana, M., Matamoros, M. A., Udvardi, M., \& Dalton, D. A. (2010). Recent insights into antioxidant defenses of legume root nodules. New Phytologist, 188(4), 960-976.
Benedito, V. A., Torres-Jerez, I., Murray, J. D., Andirankaja, A., Allen, S., Kakar, K., Wandrey, M., Verdier, J., Zuber, H., \& Ott, T. (2008). A gene expression atlas of the model legume Medicago truncatula. Plant Joumal, 55, 504-513.

Bradford, M. A. (1976). Rapid and sensitive method for the quantization of the microgram quantities of protein utilizing: The principle of protein-dye binding. Analytical Biochemistry, 72, 248-254.

de Deus, K. E., Lanna, A. C., Abreu, F. R. M., Silveira, R. D. D., Pereira, W. J., Brondani, C., \& Vianello, R. P. (2015). Molecular and biochemical characterization of superoxide dismutase (SOD) in upland rice under drought. Australian Journal of Crop Science, 9(8), 744-753.

Du, W, Gardea-Torresdey, J. L., Ji, R., Yin, Y., Zhu, J., Peralta-Videa, J. R., \& Guo, H. (2015). Physiological and biochemical changes imposed by $\mathrm{CeO}_{2}$ nanoparticles on wheat: A life cycle field study. Environtal Science Technology, 49(19), 11884-11893.

Foyer, C. H., \& Noctor, G. (2005). Redox homeostasis and antioxidant signaling: A metabolic interface between stress perception and physiological responses. Plant Cell, 17(7), 1866-1875.

Furlan, A. L., Bianucci, E., Tordable, M. C., Castro, S., \& Dietz, K. J. (2014). Antioxidant enzyme activities and gene expression patterns in peanut nodules during a drought and rehydration cycle. Functional Plant Biology, 41(7), 704-713.

Gogorcena, Y., Iturbe-Ormaetxe, I., Escuredo, P. R., \& Becana, M. (1995). Antioxidant defenses against activated oxygen in pea nodules subjected to water stress. Plant Physiology, 108(2), 753-759.

Gutiérrez-Martínez, P. B., Torres-Morán, M. I., Romero-Puertas, M. C., Casas-Solís, J., Zarazúa-Villaseñor, P., Sandoval-Pinto, E., \& Ramírez-Hemández, B. C. (2020). Assessment of antioxidant enzymes in leaves and roots of Phaseolus vulgaris plants under cadmium stress. Biotecnia, 22(2), 110-118.

Hasanuzzaman, M., Borhannuddin Bhuyan, M. H. M., Anee, T. I., Parvin, K., Nahar, K., Mahmud, J. A., \& Fujita, M. (2019). Regulation of ascorbate-glutathione pathway in mitigating oxidative damage in plants under abiotic stress. Antioxidants, 8(9), 1-50.

Ivanova, K. A., \& Cygankov, V. E. (2017). Antioksidantnaya sistema zashchity v simbioticheskih kluben'kah bobovyh rastenij [Antioxidant defense system in symbiotic nodules of legumes]. Selskokhozyajstvennaya Biologiya, 52(5), 878 894 (in Russian).

Jaspers, P., \& Kangasjärvi, J. (2010). Reactive oxygen species in abiotic stress signaling. Plant Physiology, 138(4), 405-413.

Jebara, S., Jebara, M., Limam, F., \& Aouani, M. E. (2005). Changes in ascorbate peroxidase, catalase, guaiacol peroxidase and superoxide dismutase activities in common bean (Phaseolus vulgaris) nodules under salt stress. Plant Physiology, $162,929-936$.

Kaplunenko, V. G., \& Kosinov, M. V. (2009). Nadchystyi vodnyi rozchyn nanokarboksylatu metalu [Ultrapure aqueous solution of metal nanocarboxylate]. Patent 39397UA. Publ. 25.02.2009. Bul. 4 (in Ukrainian).

Kole, C., Kole, P., Randunu, K. M., Choudhary, P., Podila, R., Ke, P. C., Rao, A. M., \& Marcus, R. K. (2013). Nanobiotechnology can boost crop production and quality: First evidence from increased plant biomass, fruit yield and phytomedicine content in bitter melon (Momordica charantia). Biotechnology, 13(1), 37.

Kosinov, M. V., \& Kaplunenko, V. H. (2008). Sposib otrymannia ekolohichno chystykh nanochastynok elektroprovidnykh materialiv "elektroimpulsna abliatsiia" [Method of producing ecologically clean nanoparticles of electro-conductive materials "electric impulse ablation"]. Patent 37412UA. Publ. 25.11.2008. Bul. 22 (in Ukrainian).

Kots, S. Y., Rybachenko, L. I., Pukhtaievych, P. P., \& Mokrytskyi, K. A. (2019). Formuvannia ta funktsionuvannia symbiotychnykh system soia - Bradyrhizobium japonicum za vplyvu kompleksiv nanochastynok karboksylativ mikroelementiv [Formation and functioning of symbiotic systems of soybean - Bradyrhizobium japonicum under the influence of complexes of nanoparticles of carboxylates of microelements]. Silskohospodarska Mikrobiolohiia, 29, 12-20 (in Ukrainian).

Kots, S. Y., \& Vorobei, N. A. (2018). Shtam bakterii Bradyrhizobium japonicum B7538 dlia oderzhannia bakterialnoho dobryva pid soiu [Bacterial strain Bradyrhizobium japonicum B-7538 for bacterial fertilizer under soybean]. Patent 126060 UA. Publ. 11.06.2018. Bul. 11 (in Ukrainian).

Kunert, K. J., Vorster, B. J., Fenta, B. A., Kibido, T., Dionisio, G., \& Foyer, C. H. (2016). Drought stress responses in soybean roots and nodules. Frontiers Plant Science, 7, 1015.

Laxa, M., Liebthal, M., Telman, W., Chibani, K., \& Dietz, K.-J. (2019). The role of the plant antioxidant system in drought tolerance. Antioxidants, 8(4), 1-31.

Mamenko, T. P., Khomenko, Y. O., \& Kots, S. I. (2018). Aktyvnist superoksyddysmutazy ta enzymiv askorbat-hlutationovoho tsyklu u symbiotychnykh systemakh Glycine max - Bradyrhizobium japonicum za dii posukhy [Activity of superoxide dismutase and ascorbate-glutathione cycle enzymes in symbiotic systems Glycine max - Bradyrhizobium japonicum under drought]. Mikrobiolohichnyi Zhurnal, 80(3), 77-88 (in Ukrainian).

Matamoros, M. A., Dalton, D. A., Ramos, J., Clemente, M. R., Rubio, M. C., \& Becana, M. (2003). Biochemistry and molecular biology of antioxidants in the rhizobia-legume symbiosis. Plant Physiology, 133(2), 499-509. 
Mhamdi, A., \& Van Breusegem, F. (2018). Reactive oxygen species in plant development. Development, 145(15), 1-12.

Moran, J. F., James, E. K., Rubio, M. C., Sarath, G., Klucas, R. V., \& Becana, M. (2003). Functional characterization and expression of a cytosolic iron-superoxide dismutase from cowpea root nodules. Plant Physiology, 133(2), 773-782.

Palma, F., López-Gómez, M., Tejera, N. A., \& Lluch, C. (2013). Salicylic acid improves the salinity tolerance of Medicago sativa in symbiosis with Sinorhizobium meliloti by preventing nitrogen fixation inhibition. Plant Science, 208, 75-82.

Pauly, N., Pucciariello, C., Mandon, K., Innocenti, G., Jamet, A., Baudouin, E. Hérouart, D., Frendo, P., \& Puppo, A. (2006). Reactive oxygen and nitrogen species and glutathione: Key players in the legume-Rhizobium symbiosis. Journal of Experimental Botany, 57(8), 1769-1776.

Porcel, R., Barea, J. M., \& Ruiz-Lozano, J. M. (2003). Antioxidant activities in mycorrhizal soybean plants under drought stress and their possible relationship to the process of nodule senescence. New Phytologist, 157(1), 135-143.

Pradhan, S., Patra, P., Das, S., Chandra, S., Mitra, S., Dey, K. K., Akbar, S., Palit, P., \& Goswami, A. (2013). Photochemical modulation of biosafe manganese nanoparticles on Vigna radiata: A detailed molecular, biochemical, and biophysical study. Environtal Science Technology, 47(22), 13122-13131.

Raychauhuri, S. S., \& Deng, X. W. (2000). The role of superxide dismutase in combating oxidative stress in higher plants. The Botanical Review, 66(1), 89-98.

Rubio, M. C., Becana, M., Sato, S., James, E. K., Tabata, S., \& Spaink, H. P. (2007). Characterization of genomic clones and expression analysis of the three types of superoxide dismutases during nodule development in Lotus japonicus. Molecular Plant-Microbe Interactions, 20(3), 262-275.

Rubio, M. C., James, E. K., Clemente, M. R., Bucciarelli, B., Fedorova, M., Vance, C. P., \& Becana, M. (2004). Localization of superoxide dismutases and hydrogen peroxide in legume root nodules. Molecular Plant-Microbe Interactions, 17(12), 1294-1305.

Santos, R., Hérouart, D., Puppo, A., \& Touati, D. (2000). Critical protective role of bacterial superoxide dismutase in Rhizobium-legume symbiosis. Molecular Microbiology, 38(4), 750-759.
Sarker, U., \& Oba, S. (2018). Catalase, superoxide dismutase and ascorbate-glutathione cycle enzymes confer drought tolerance of Amaranthus tricolor. Scientific Reports, 8(1), 1-12.

Suzuki, N., Koussevitzky, S., Mittler, R., \& Miller, G. (2012). ROS and redox signaling in the response of plants to abiotic stress. Plant, Cell and Environment, $35(2), 259-270$

Talukdar, D., \& Talukdar, T. (2013). Superoxide-dismutase deficient mutants in common beans (Phaseolus vulgaris L.): Genetic control, differential expressions of isozymes, and sensitivity to arsenic. Biomed Research International, 372,782450 .

Taran, N., Batsmanova, L., Kovalenko, M., \& Okanenko, A. (2016). Impact of metal nanoform colloidal solution on the adaptive potential of plants. Nanoscale Research Letter, 11(89), 1-6.

Tejera, N. A., Campos, R., Sanjuán, J., \& Lluch, C. (2004). Nitrogenase and antioxidant enzyme activities in Phaseolus vulgaris nodules formed by Rhizobium tropici isogenic strains with varying tolerance to salt stress. Plant Physiology, 161(3), 329-338.

Tyagi, S., Sharma, S., Taneja, M., Shumayla, Kumar, R., Sembi, J. K., \& Upadhyay, S. K. (2017). Superoxide dismutases in bread wheat (Triticum aestivum L.): Comprehensive characterization and expression analysis during development and, biotic and abiotic stresses. Agri Gene, 6, 1-13.

Tyagi, S., Shumayla, Madhu, Singh, K., \& Upadhyay, S. K. (2021). Molecular characterization revealed the role of catalases under abiotic and arsenic stress in bread wheat (Triticum aestivum L.). Journal of Hazardous Materials, 403, 123585.

Udvardi, M. K., \& Poole, P. S. (2013). Transport and metabolism in legumeRhizobia symbioses. Annual Review of Plant Biology, 64(1), 781-808.

Wisniewski, J. P., Rathbun, E. A., Knox, J. P., \& Brewin, N. J. (2000). Involvement of diamine oxidase and peroxidase in insolubilization of the extracellular matrix: Implications for pea nodule initiation by Rhizobium leguminosarum. Molecular Plant-Microbe Interactions, 13(4), 413-420.

Wu, J., Wang, X.,Wang, Q., Lou, Z., Li, S., Zhu, Y., Qin, L., \& Wei, H. (2019). Nanomaterials with enzyme-like characteristics (nanozymes): Next-generation artificial enzymes (II). Chemical Society Reviews, 48(4), 1004-1076. 